\title{
Tectonic Significance of Porosity and Permeability Regimes in the Red Beds Formations of the South Georgia Rift Basin
}

\author{
Olusoga M. Akintunde*, Camelia C. Knapp, and James H. Knapp \\ Department of Earth and Ocean Sciences, University of South Carolina, Columbia, South
}

Carolina 29208, USA

*Corresponding author.

$+18037773143$

olusogamartins@gmail.com

701 Sumter Street, EWS 617

Columbia, SC 29208. 


\section{ABSTRACT}

A simple, new porosity/permeability-depth profile was developed from available laboratory measurements on Triassic sedimentary red beds (sandstone) from parts of the South Georgia Rift (SGR) basin in order to investigate the feasibility for long-term $\mathrm{CO}_{2}$ storage. The study locations were: Sumter, Berkeley, Dunbarton, Clubhouse Crossroad-3 (CC-3) and Norris Lightsey wells. As expected, both porosity and permeability show changes with depth at the regional scale that was much greater than at local scale. The significant changes in porosity and permeability with depth suggest a highly compacted, deformed basin, and potentially, a history of uplift and erosion. The permeability is generally low both at shallow (less than $1826 \mathrm{ft} / 556.56 \mathrm{~m}$ ) and deeper depths (greater than $1826 \mathrm{ft} / 556.56 \mathrm{~m}$ ). Both porosity and permeability follow the normal trend, decreasing linearly with depth for most parts of the study locations with the exception of the Norris Lightsey well. A petrophysical study on a suite of well logs penetrating the Norris Lightsey red beds at depths sampled by the core-derived laboratory measurements shows an abnormal shift (by 50\%) in the acoustic travel time and/or in the sonic-derived P-wave velocity that indicates possible faulting or fracturing at depth. The departure of the Norris Lightsey's porosities and permeabilities from the normal compaction trend may be a consequence of the existence of a fault/fracture controlled abnormal pressure condition at depth. The linear and nonlinear behaviors of the porosity/permeability distribution throughout the basin imply the composition of the SGR red beds, and by extension analog/similar Triassic-Jurassic formations within the Eastern North American Margin has been altered by compaction, uplift, erosion and possible faulting that have shaped the evolution of these Triassic formations following the major phase of rifting. 


\subsection{INTRODUCTION}

In this study, we explore and demonstrate a possible link between rock physics and tectonic evolution of the SGR basin in the light of unraveling of geological observations of key tectonic importance from core-derived porosity and permeability data. This is an area of research that is different from the usual petrophysical interpretations of porosity and permeability data for reservoir and production applications notably in oil and gas exploration since it involves understanding the impacts of key geologic controls on porosity and permeability trends in a rift basin. Rock physics involves the study of physical properties of rocks such as porosity and permeability and how these are related to geophysical observations (Mavko et al., 1998). Porosity is the relative amount of pore space in a rock while permeability is the ability of a rock to transmit fluid (Schon, 2011). Both are very important in assessing reservoir storage capacity as well as the degree of reservoir quality and compartmentalization for the purpose of oil and gas recovery, subsurface storage of $\mathrm{CO}_{2}$ and any other dynamic reservoir systems that involve fluid movement. As pore space properties of rocks, porosity and permeability are primarily dependent on the size, shape, distribution, and packing or sorting of the grains in the rock (Schon, 2011). Physical, chemical and geo-chemical processes including diagenesis and changes in the mineralogy are other factors that can influence porosity and permeability in rocks. The focus of this study is on the role of tectonically induced post depositional processes on the present-day porosity and permeability within the Triassic-Jurassic SGR basin. This is an area of research not previously examined for the SGR basin. The goal is to interpret and analyze the porosity/permeability variations with depth locally and regionally in order to (1) investigate the physical controls responsible for the present-day porosity and permeability regimes as well as (2) 
gain new insights into the implications of the observed porosity and permeability changes for the tectonic evolution of the basin.

\subsection{BACKGROUND GEOLOGY}

The SGR basin (Figure 1), which is separated from the Piedmont Crystalline rocks by the Fall line, is buried below the Cretaceous-Cenozoic Coastal Plain sediments of South Carolina, Georgia, Alabama and Florida. It also possibly extends offshore from the eastern Gulf Coast to the Atlantic Coast (Heffner et al., 2012, Daniels et al., 1983). The SGR basin is also thought to be the largest and probably the most geologically complex Mesozoic basin of the Eastern North American Margin (ENAM) formed during crustal extension associated with the breakup of Pangea and later opening of the North Atlantic Ocean (Popenoe and Zietz, 1977). The ENAM is a regionally extensive and mature Mesozoic passive margin rift system covering the Central Atlantic Magmatic Province as well as other preserved stratigraphic column that records the post-rift evolution in several of the early Mesozoic basins. These basins including the sub-basins within the SGR basin are characterized by the presence of half grabens and are generally filled with red beds or sandstones (McBride et al., 1989, and Petersen et al., 1984). Pronounced igneous activity following rifting led to the formation of basalt flows and emplacement of diabase dikes and sills (Daniels et al., 1983). The two main facies of red beds recognized throughout the basin are the (1) fine-to-medium grained sandstones interbedded with mudstones and siltstones, and (2) coarse-grained or conglomeratic sandstones (Gohn et al., 1983 and Akintunde et al., 2013). 


\subsection{MATERIAL AND METHODS}

New porosity and permeability data were obtained from Sumter, Berkeley, and the CC-3 wells using standard laboratory measurements carried out on 1.5 inch diameter core plugs (Gomez et al., 2010). The measurements were done using the Automated Core Measurement System (CMS-300) at the Rock Abuse Laboratory at the Colorado School of Mines (CSM), Golden, Colorado. The CMS-300 is a product of Core Laboratories Incorporation and it combines porosimeter and permeameter in one instrument to determine porosity and permeability. In order to provide an independent verification as well as assure on the quality of the data, repeat measurements were carried out on the Berkeley samples at the Weatherford Laboratories (WL) in Golden, Colorado. Measurements obtained for the Berkeley samples at both the CSM and WL laboratories were virtually the same (Table 1) thereby increasing confidence in the reliability and quality of the porosity and permeability data. Existing porosity and permeability data from the Dunbarton basin (Marine and Siple, 1974) and Norris Lightsey well were used to supplement the new experimental data (Table 1). Core Laboratories Incorporation, Dallas, Texas in 1984, acquired the Norris Lightsey data (based on side wall coring) as part of previous efforts to explore for hydrocarbon resources. These datasets were initially interpreted in relation to a depositional environment and reservoir quality assessment as parts of geological characterization study aimed at evaluating subsurface suitability for $\mathrm{CO}_{2}$ storage within the SGR basin (Akintunde et al., 2013). The current effort is aimed at investigating the geophysical and/or geological significance of the observed porosity/permeability depth changes in relation to the tectonic evolution of the basin. Deducing geological observations of tectonic importance from rock physics data represent an area of research that is new to the SGR basin. 


\subsection{RESULTS AND DISCUSSION}

The analyzed porosity/permeability depth profiles are shown in Figures 2 and 3. This study shows that the porosity changes by up to $44 \%$ and regionally by over $100 \%$. A reduction in porosity with depth is easily noticeable at most locations with the exception of the Norris Lightsey well. We do expect porosity to be lower in deeper, older rocks and show a decreasing linear trend with depth due to increasing effects of compaction and cementation. The reduction in permeability with increasing depth below the surface follows the same trend in most of the study locations apart from the Norris Lightsey (Figure 3). In the Berkeley, Norris Lightsey and the CC-3 wells, the permeability changes by $93 \%, 83 \%$ and $56 \%$ respectively. The permeability values are generally low due to the fine-grained nature of the sediments, poor sorting, presence of small pore throats and poor rounding of grains (Marine and Siple, 1974; Akintunde et al., 2013). The low permeabilities in the CC-3 and Dunbarton locations favor safe storage of $\mathrm{CO}_{2}$ since these are below the range of seismogenic permeability likely to cause induced seismicity with fluid injection (Talwani et al., 2007).

Four key observations stand out in the porosity/permeability depth models (Figure 2 and 3): (1) a general lack of significant correlation of porosity/permeability with depth throughout the basin ( $\mathrm{R}^{2}$ of 0.2830 and 0.5181 obtained for the porosity-depth and permeability-depth profiles), (2) a linear decrease of porosity with depth for all other study locations with the exception of the Norris Lightsey, (3) the unusually higher porosities and permeabilities for the deeply buried Norris Lightsey red beds relative to other parts of the basin such as Berkeley and Sumter wells that are shallower and the CC-3 and Dunbarton wells that occur at near-similar depths, and (4) the non-conformity of the Norris Lightsey porosity-depth distribution with the normal 
compaction trend. The first observation, whereby we see both a linear and non-linear increase in porosity/permeability with depth is often encountered in a basin that has undergone differential uplift and erosion (Bloch, 1991). These rocks are all part of the Atlantic-type passive continental rift deposits, however there is no evidence to suggest that the sedimentary fill in these locations at present is what it was during the early cycle of sedimentation that accompanied rifting and continental separation. It is likely that erosion during Jurassic removed large volumes of rocks including several parts of the top of the Triassic sediments as well as uncovering part of the crystalline basement rock. Furthermore, tectonic events including extrusion of basaltic flows and intrusion of diabase sills, which postdate basin-filling during early to late Jurassic, likely have played a significant role in post depositional processes that can trigger induced porosity and permeability within the basin. The fact that the observed regional changes in the porosity-depth trend (Figure 2) lack a uniform pattern suggest that these post-rift events may have occurred disproportionately within or in some parts of the basin. This in turn may lead to variations in the degree of tectonically induced physical processes that may influence porosity/permeability-depth distributions.

The linear dependency of porosity with depth observed for most parts of the study area (Figure 2) is an indication of a highly compacted, deformed basin. The compaction/porosity-depth model shows a porosity of above $10 \%$ at the near surface and then decreases significantly with depth especially in the CC-3 and Dunbarton wells (Figures 2 and 4). The occurrence of the CC-3 red beds to within few tens of meters to the underlying crystalline basement rock as implied in seismic refraction study by Ackermann (1983) as well as presence of $256 \mathrm{~m}$ thick of basalt flows (Akintunde et al., 2013) directly on top of the CC-3 red beds suggest strongly compacted sediments. The consequence of this is a reduction in porosity as observed in the unusually low 
porosity and permeability for the CC-3 red beds. Evidence for compaction is further strengthened by the significantly high P-wave velocities of 5.5-6.7 km/s reported in Marine (1974) for the Dunbarton Triassic sediments at depths $(3000-4000 \mathrm{ft})$ covered by the core-derived porosity and permeability data. Sediment compaction closes cracks and openings in a rock leading to increases in both the confining stress and seismic velocity.

The third and fourth observations, involving the non-linear behavior of the Norris Lightsey porosity-depth distribution as well as its unusually higher porosities and permeabilities relative to the CC-3 and Dunbarton red beds occurring at near similar depths, present an issue of scientific importance to the tectonic evolution of the basin. As reported in Marine (1974), analysis of Triassic samples from 5 wells within Dunbarton show extremely low permeability ranging from $4.5 * 10-6 \mathrm{mD}$ to $1.6 * 10-2 \mathrm{mD}$ over the depth range of $1272 \mathrm{ft}$ to $4260 \mathrm{ft}$. Moreover, an average porosity of $6.3 \%$ was recorded for all Triassic samples tested. The low permeability observed in the Dunbarton and the CC-3 Triassic samples is caused by poor sorting which is a characteristic common to both the fine and coarse grained Triassic red beds of the SGR basin. Evidence for the poor sorting is provided in a study by Marine and Siple (1974) involving thin section analysis and mechanical analyses of clay, silt, sand and gravel contents on Triassic red beds cores from Dunbarton. Petrographic evidence for the poor sorting of the CC-3 red beds is well documented in the analysis of photomicrographs of thin sections presented in Gohn et al., 1983, and Akintunde et al., 2013. Due to the lack of cores for the Norris Lightsey well, we could not perform a petrographic study to help ascertain whether or not the red beds sequence has been subjected to any significant alteration compositionally and texturally to have impacts on the present day porosity and permeability. What we do know from the core laboratory data (Core Lab. Report, 1984) is the presence of significantly high amounts of silt and clay in the Norris 
Lightsey samples, and which may be partly responsible for the low permeability. This high value (based on the data acquisition information from Core Laboratories, Inc.) may be partially due to a shattering of the matrix material by the impact of the sidewall sampling device. The strong correlation ( $\mathrm{R}^{2}$ of 0.9850$)$ between the measured porosities and permeabilities, for points not away the linear trend (right hand side of Figure 5), adds confidence to the reliability of the Norris Lightsey data. Sonic-derived porosity values at similar depths covered by the laboratory-derived porosity and permeability data (Figure 6) does support the observed trend from the core-derived porosities. Except for the difference in the scale of measurements, the sonic-derived porosity values show high porosities of between 15 to $20 \%$ around $4300 \mathrm{ft}$ and values greater than $20 \%$ can be seen between 3200 and $3450 \mathrm{ft}$.

Furthermore, the Norris Lightsey may be separated from other parts of the basin or occurs in association with a system of horst and grabens. Presence of grabens has been inferred from many of the fault-bounded subbasins within the SGR basin (Talwani, 1977; Hamilton et al., 1983; Schilt et al., 1983; Ratcliffe et al., 1986). This in turn can potentially alter the rock's physical properties in contrast with other parts of the basin examined in this study (Figures 1-3). This would undoubtedly strengthen previous studies showing that the SGR basin may not be a single extensional basin but a system of sub- basins and half-grabens (McBride et al., 1989).

The presence of a pre-existing structure like a fault or a fracture zone capable of perturbing the pore pressure at depth can induce secondary porosity. Evidence for this anomaly can be seen in the observed sharp increase in the acoustic travel time (sonic) log from about 78 to $157 \mu \mathrm{sec} / \mathrm{ft}$ (50\% changes) at around $3450 \mathrm{ft}$ (Figure 7). The sonic-derived P-wave velocity also decreases by $50 \%$ from 4 to $2 \mathrm{~km} / \mathrm{s}$ at this interval. This type of change in acoustic behavior at depth is often associated with a discontinuity or a break in the rock. The gamma ray readings around this 
zone varies between about 40 to 100 API that are typical of red beds consisting of interbedded mudstone/siltstone and sandstone and so the observed change in the acoustic travel time log does not indicate transition to a different rock type. There is no gas in this formation based on the responses from the resistivity, bulk density and neutron-porosity logs (Figure 7). Moreover, intervals above this abnormal pressure zone are normally pressured based on the signatures from the acoustic travel time with depth. The tectonic implication is that the Norris Lightsey well may be located on a fault-bounded half graben which could impact porosities and permeabilities at depth. Faulting or fracturing following original deposition creates voids or openings in the rock's pore space thereby increasing both porosities and permeabilities for potential fluid storage and movement.

\subsection{Consideration for the Use of Limited Porosity and Permeability Data}

There is no doubt that the key findings presented and discussed in this work have been based on limited core laboratory data for the study areas. In order to substantiate the current results, we have had to rely on existing geological records (drill cuttings, lithologic description and mineral composition as well as mechanical analyses of the clay, silt, sand and gravel contents of the Triassic red beds) for the Dunbarton location published in Marine and Siple, 1974 as well as those (photomicrographs of thin sections) discussed in Gohn et al., 1983 and more recently by Akintunde et al., 2013 for the CC-3 red beds. While more data availability could have helped to further strengthen the argument for the key observations from this work, geological consideration and/or evidence from the above referenced studies provide justification for the results and implications of the porosity/permeability-depth models for subsurface tectonics. Moreover, the use of multiple well logs information (such as porosity, gamma ray, density, induction deep lateral (ILD) resistivity and neutron-porosity) from the Norris Lightsey provide 
sufficient, corroborating evidence for the observed porosity/permeability depth trends for the area. The problem with the use of limited data, which could have impacted the reliability of the porosity/permeability to depth models, is offset by the consistency between these existing, published geological records and the observations from this work.

\subsection{CONCLUSIONS}

Two regimes of porosity-permeability distribution are recognized within the Triassic-Jurassic SGR basin based on the interpretation of porosity/permeability depth profiles. The first regime, which is characterized by low porosities and permeabilities as well as manifests a linear dependency with depth, provides evidence for a compacted, deformed basin. The second regime, which appears to be restricted to the Norris Lightsey area of the basin, shows a non-linear dependency with depth. This non-conformity to the normal compaction trend, in which porosities decrease linearly or exponentially with depth may likely result from altered or secondary porosities caused by faulting or fracturing at depth. The existence of these different regimes of porosity and permeability within the basin suggests the SGR basin may not be a single extensional basin but a subset of basins with presumably distinct geo-hydrologic systems. The depth dependencies of porosity/permeability distribution throughout the SGR basin is a function of tectonically induced post depositional processes such as compaction, uplift and erosion as well as possible faulting that have shaped the evolution of the SGR basin following the major phase of rifting. This study demonstrates that geological observations of vital importance to basin evolution can be interpreted from rock physics data or physical properties of rocks such as porosity and permeability. 


\section{ACKNOWLEDGEMENTS}

We would like to thank John Shafer, Mike Waddell, Adrian Addison, Duke Brantley and Mark

Evans from the Earth Sciences and Resources Institute (ESRI), USC-Columbia, South Carolina,

David Heffner, Department of Earth and Ocean Sciences, as well as Scott Howard and Bill

Clendenin of the South Carolina Geological Survey. We thank Dr. Manika Prasad and Dr. Mike

Batzle, Colorado School of Mines, Golden, Colorado for permission to use their laboratory

facilities. This material is based upon work supported by the United States Department of Energy

(DOE) under Award Number DE-FE0001965.This paper was prepared as an account of work

sponsored by an agency of the United States Government. Neither the United States Government

nor any agency thereof, nor any of their employees, make any warranty, express or implied, or

assumes any legal liability or responsibility for the accuracy, completeness, or usefulness of any

information, apparatus, product, or process disclosed, or represents that its use would not

infringe privately owned rights. Reference herein to any specific commercial product, process, or

service by trade name, trademark, manufacturer, or otherwise does not necessarily constitute or

imply its endorsement, recommendation, or favoring by the United States Government or any

agency thereof. The views and opinions of authors expressed herein do not necessarily state or

reflect those of the United States Government or any agency thereof.

\section{REFERENCES}

Ackerman, H.D., 1983. Seismic refraction study in the area of the Charleston, South Carolina earthquake, in Gohn, G.S., ed., studies related to the Charleston, South Carolina, earthquake of 1886 - Tectonics and seismicity. U.S. Geological Survey Professional Paper 1313, F1-F20.

Akintunde O.M, Knapp, C.C., Knapp, J.H., 2013. Petrophysical characterization of the South Georgia Rift basin for supercritical $\mathrm{CO}_{2}$ storage: a preliminary assessment. Environmental Earth Science 70, 2971-2985 
Bloch, S., 1991. Empirical prediction of porosity and permeability in sandstones. American Association of Petroleum Geologists Bulletin, v.75, no. 7, 1145-1160.

Chowns, T.M., Williams, C.T., 1983. Pre-Cretaceous rocks beneath the Georgia Coastal plain regional implications, in Gohn, G.S., ed., studies related to the Charleston, South Carolina, earthquake of 1886 - Tectonics and seismicity. US Geological Survey Professional paper 1313, L1-L42.

Daniels, D.L., Zietz, I., Popenoe, P., 1983. Distribution of subsurface lower Mesozoic rocks in the southeastern United States as interpreted from regional aeromagnetic and gravity maps, in Gohn, G.S., ed., studies related to the Charleston, South Carolina, earthquake of 1886 Tectonics and seismicity. U.S. Geological Survey Professional paper 1313, K1-K24.

Gohn, G.S., Houser, B.B., Schneider, R.R., 1983. Geology of the lower Mesozoic (?) rocks in Clubhouse Crossroads test hole \#3 near Charleston, South Carolina, in Gohn, G.S., ed., studies related to the Charleston, South Carolina, earthquake of 1886-tectonics and seismicity. US Geological Survey Professional Paper 1313, D1-D17.

Gomez, T.C., Dvorkin, J., Vanorio, T., 2010. Laboratory measurements of porosity, permeability, resistivity, and velocity on Fontainebleau sandstones. Geophysics, v. 75, no.6, E191-E204.

Hamilton, R. M., Behrendt, J.C., Ackermann, H.D., 1983. Land multichannel seismic reflection evidence for tectonic features near Charleston, South Carolina, in G. S. Gohn, ed., studies related to the Charleston, South Carolina, earthquake of 1886: Tectonics and seismicity. U.S. Geological Survey Professional Paper 1313, 11-118.

Heffner, D.M., Knapp, J.H., Akintunde, O.M., Knapp, C.C., 2012. Preserved extent of Jurassic flood basalt in the South Georgia Rift: A new interpretation of the J horizon. Geology, V.40, no. $2,167-170$.

Marine, W., 1974. Geohydrology of buried Triassic basin at Savannah River Plant, South Carolina. American Association of Petroleum Geologists Bulletin, v.58, no.9, 1825-1837.

Marine W., Siple, G.E., 1974. Buried Triassic basin in the central Savannah River area. J. Geol Soc Am. Bull. 85, 311-320.

Mavko, G., Mukerji, T., Dvorkin, J., 1998. The Rock Physics Handbook, first ed. Cambridge, United Kingdom.

McBride, J.H., Nelson, K.D., Brown, L.D., 1989. Evidence and implications of an extensive early Mesozoic rift basin and basalt/diabase sequence beneath the southeast coastal plain. Geological Society of America Bulletin, v. 101, 512-520. 
Petersen, T.A., Brown, L.D., Cook, F.A., Kaufman, S., Oliver, J.E., 1984. Structure of the Riddleville basin from COCORP seismic data and implications for reactivation tectonics. Journal of Geology, v. 92, 261-271.

Popenoe, P., Zietz, I., 1977. The nature of the geophysical basement beneath the coastal plain of South Carolina and northeast Georgia, in Rankin, D.W., ed., studies related to the Charleston, South Carolina, earthquake of 1886 - a preliminary report. U.S. Geological Survey Professional Paper 1028, 119-137.

Ratcliffe, N. M., Burton, W.C., D’Angelo, R.M., Costain, J.K., 1986, Low-angle extensional faulting, reactivated mylonites and seismic reflection geometry of the Newark Basin margin in eastern Pennsylvania. Geology, v. 14, 766-770.

Schilt, F. S., Brown, L.D., Oliver, J.E., Kaufman, S., 1983. Subsurface structure near Charleston, South Carolina: Results of COCORP reflection profiling in the Atlantic Coast Plain, in G. S. Gohn, ed., Studies related to the Charleston, South Carolina, earthquake of 1886: Tectonics and seismicity. U.S. Geological Survey Professional Paper 1313, H1-H19.

Schon, J.H., 2011. Physical Properties of Rocks, first ed. Elsevier, Amsterdam.

Talwani, P., Chen, L., Gahalaut, K., 2007. Seismogenic permeability, Ks. Journal of Geophysical Research, vol. 112, B07309, doi: 10.1029/2006JB004665

Talwani, P., 1977, A preliminary shallow crustal model between Columbia and Charleston, South Carolina, determined from quarry blast monitoring and other geophysical data, in D. W. Rankin,ed., studies related to the Charleston, South Carolina, earthquake of 1886: A preliminary report. U.S. Geological Survey Professional Paper 1028, 177-187. 


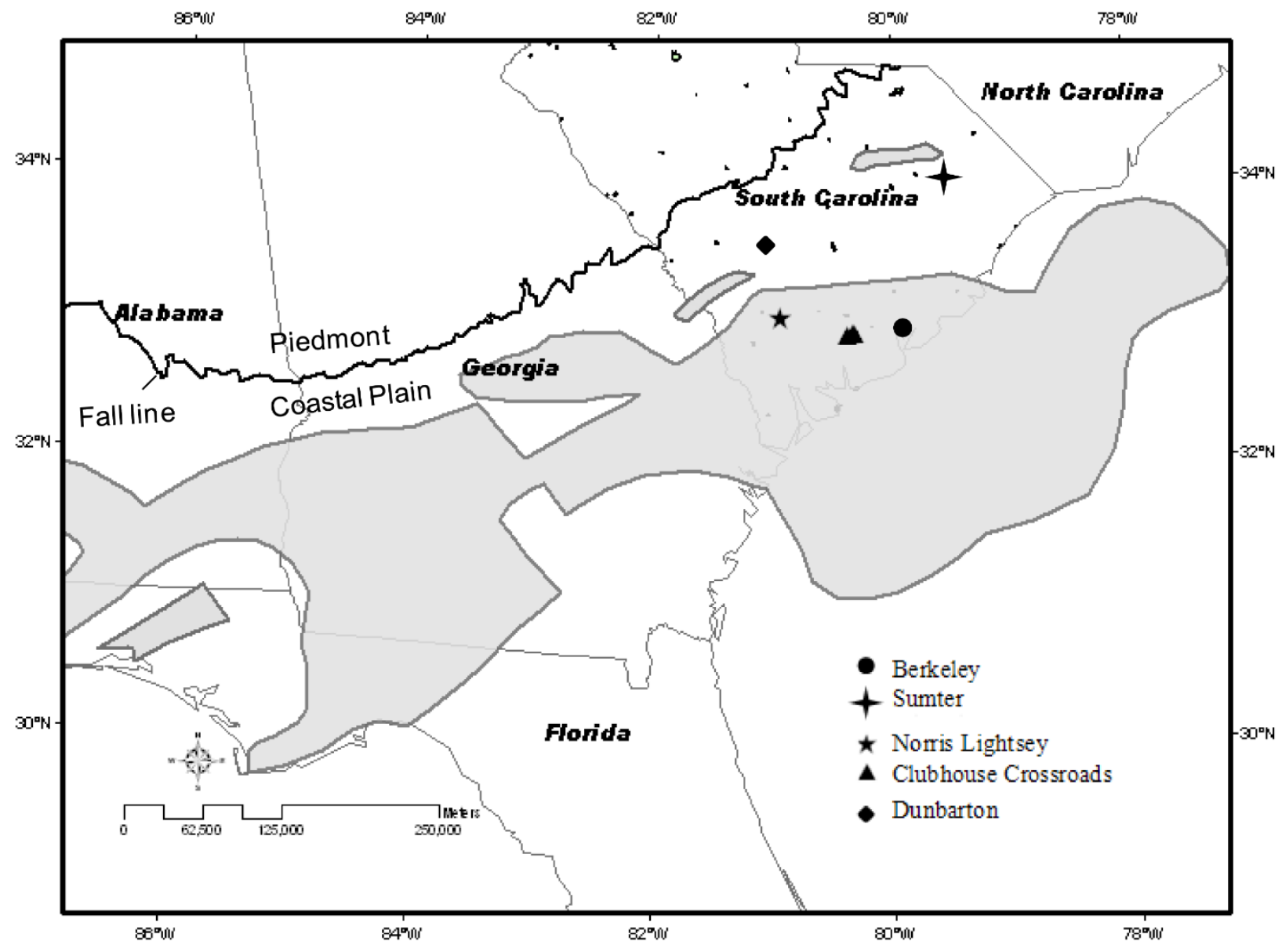




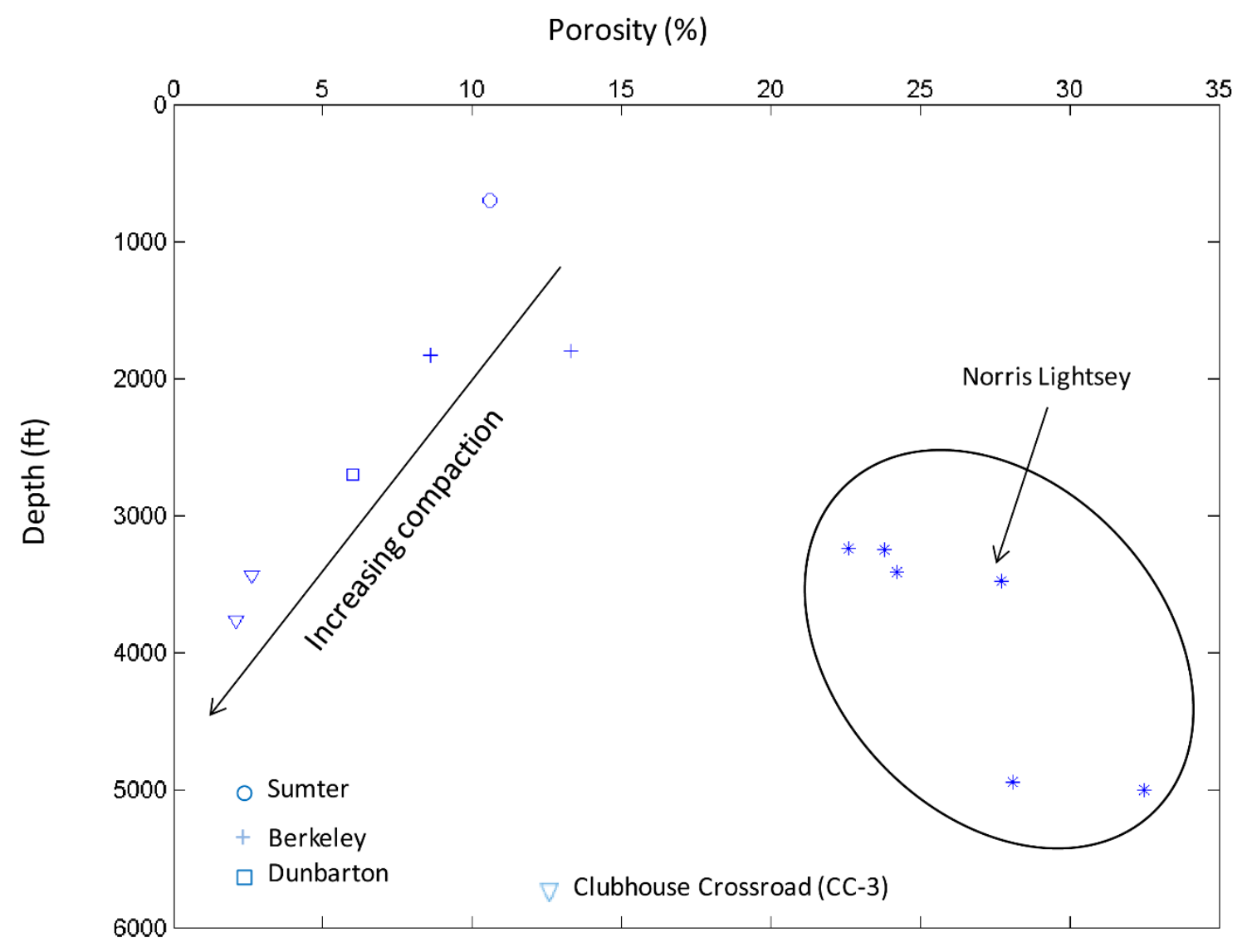




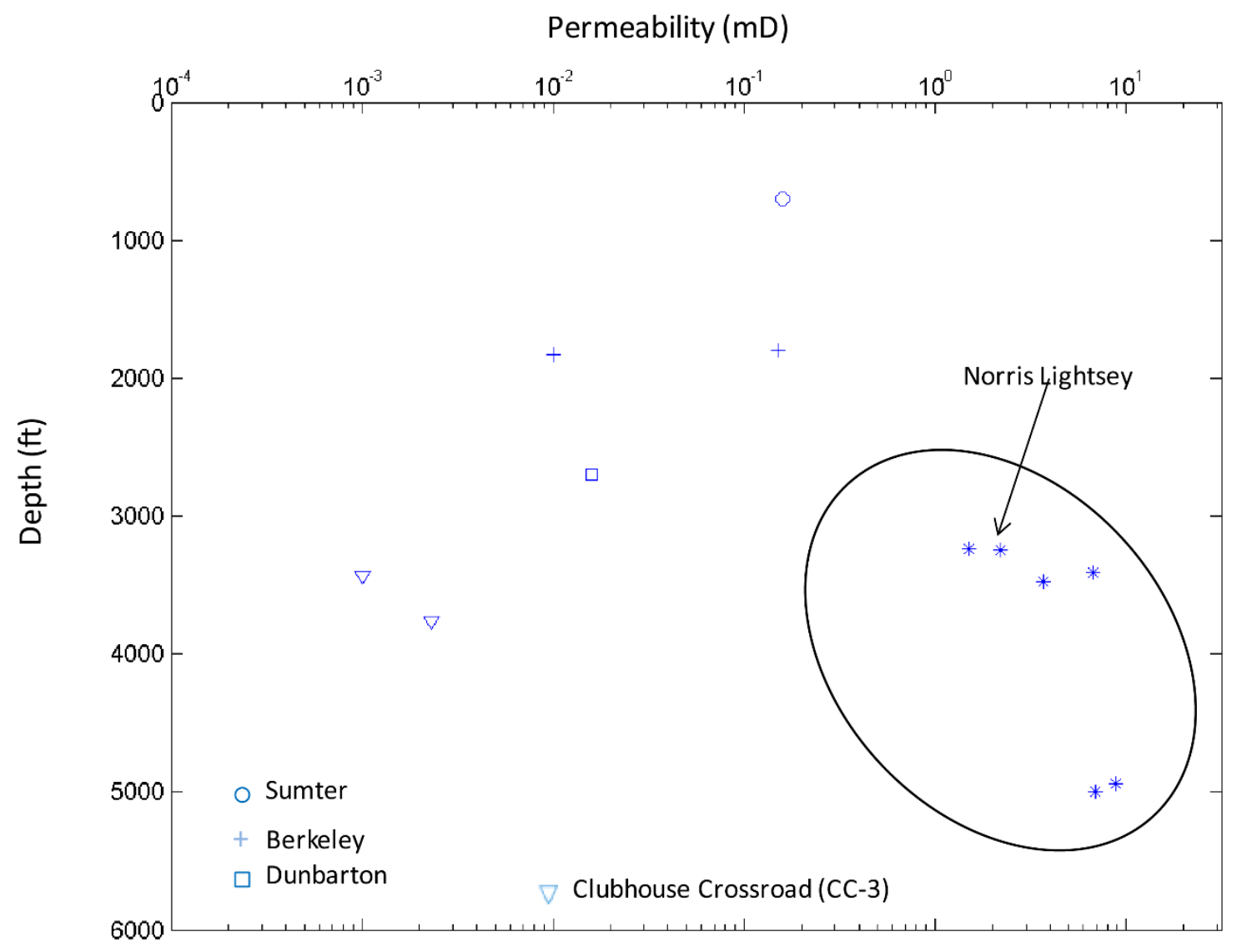




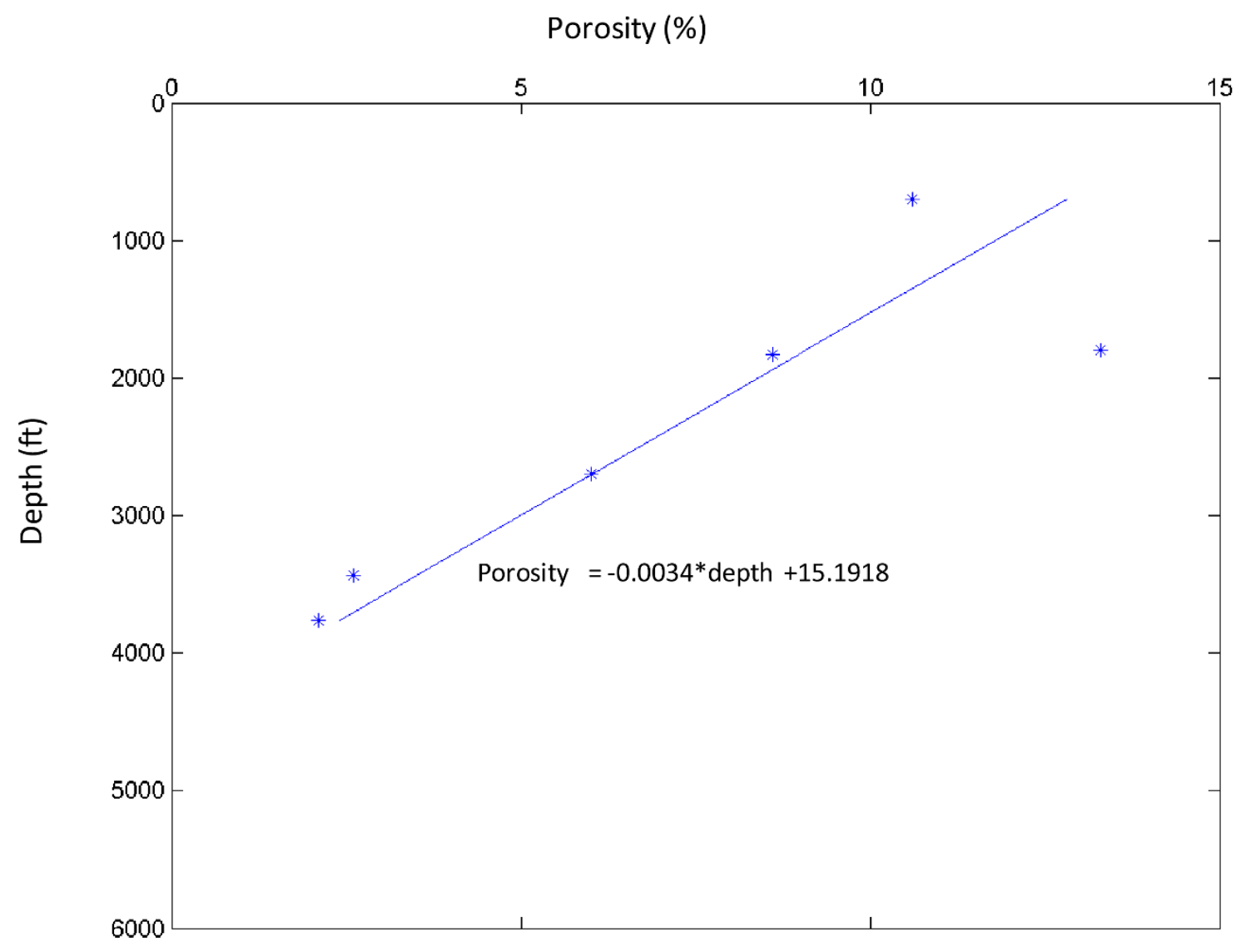



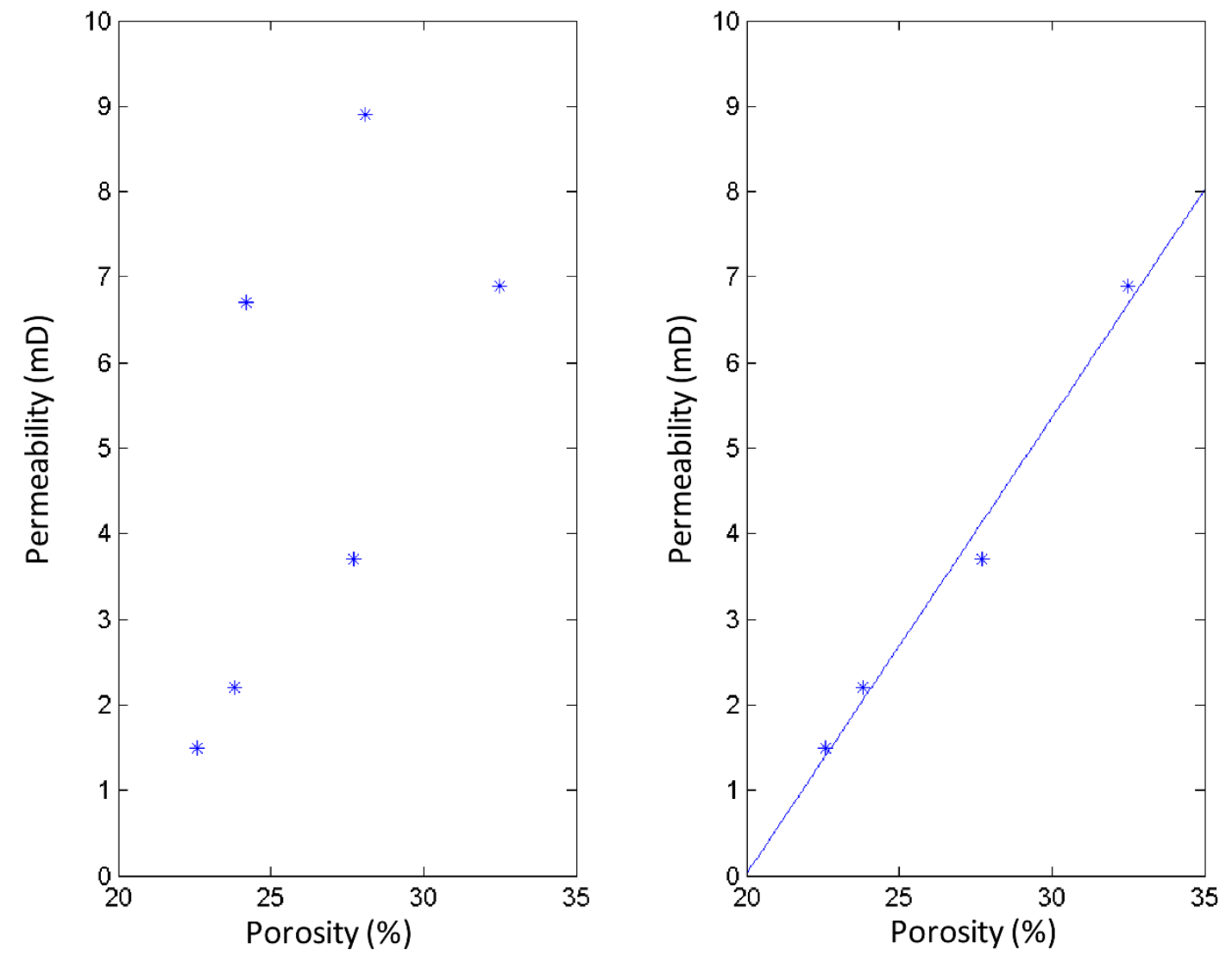

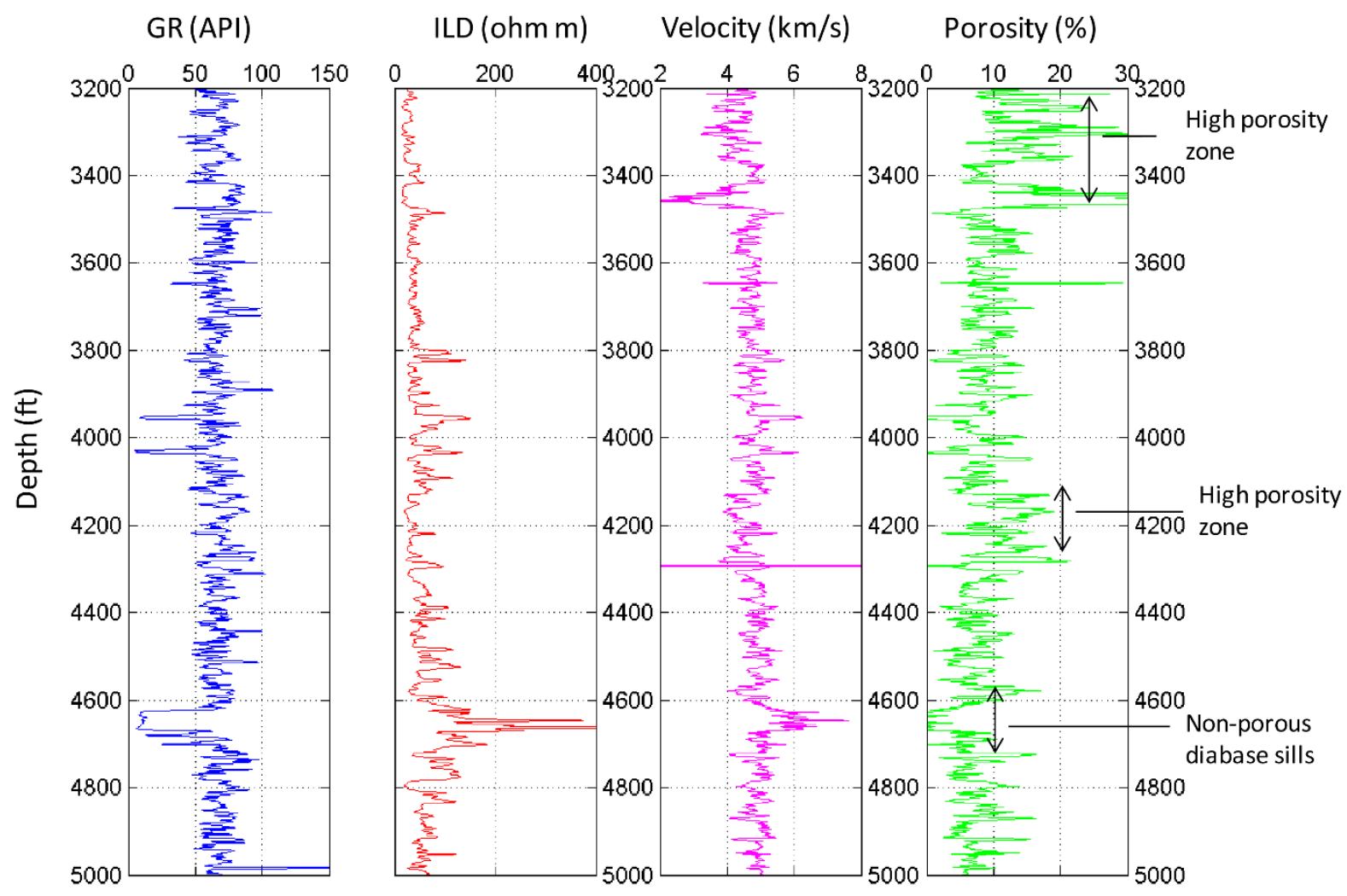


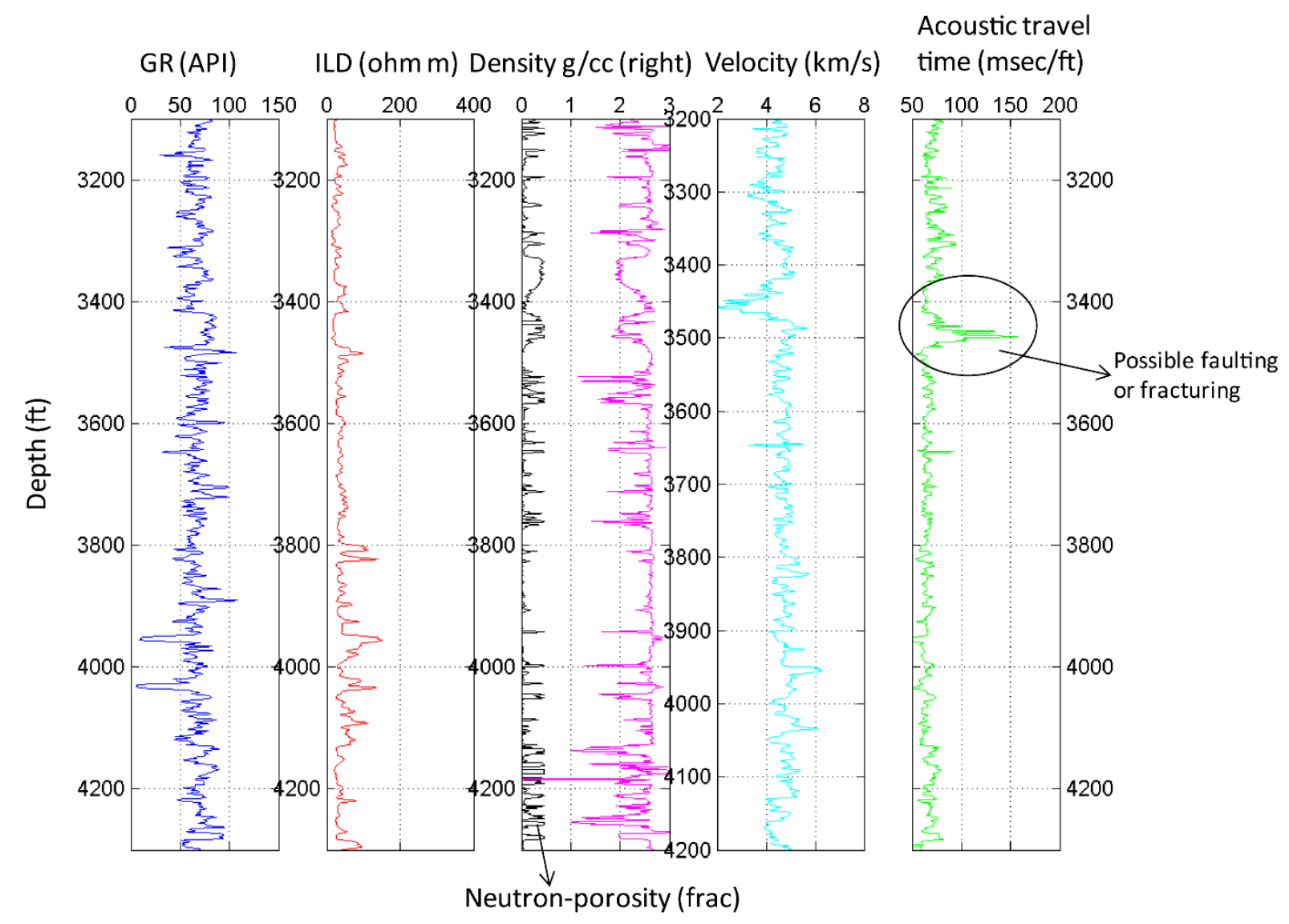




\section{FIGURE CAPTIONS}

Figure 1: A schematic of the areal extent of the South Georgia Rift basin (modified from Chowns and Williams, 1983) showing the study locations (Sumter, Berkeley, Clubhouse CrossRoad, Dunbarton and Norris Lightsey). Gray shaded area represents the areal extent of the basin

Figure 2: Porosity versus depth plot for the sampled locations.

Figure 3: Permeability versus depth plot for the sampled locations.

Figure 4: Compaction/porosity-depth model

Figure 5: Porosity-permeability plot for the Norris Lightsey. All data points are shown on the left and data points with strong positive correlation 0.986 shown on the right.

Figure 6: Plots of well logs comprising gamma ray, Induction Lateral Deep (ILD) resistivity, velocity, density and porosity.

Figure 7: A suite of well logs to demonstrate a possible fault-induced abnormal pore pressure condition at depth in the Norris Lightsey well. The well logs (from left) are gamma ray, Induction Lateral Deep (ILD) resistivity, neutron-porosity (black curve) plotted alongside density (on the right), velocity, and the acoustic travel time. 
Table 1: Core derived porosity and permeability data for the study locations (Akintunde et al., 2013)

\begin{tabular}{|l|l|l|l|l|l|}
\hline S/N & Sample ID & Depth (ft) & $\begin{array}{l}\text { Porosity } \\
(\%)\end{array}$ & $\begin{array}{l}\text { Permeability } \\
(\mathrm{mD})\end{array}$ & Source (year) \\
\hline 1 & Sumter & 699.02 & 10.6 & 0.16 & This study: WL (2011) \\
\hline 2 & Berkeley_1 & 1799.02 & 13.3 & 0.15 & This study: WL (2011) \\
\hline 3 & Berkeley_1a & 1799.02 & 13.0 & 0.10 & This study: CSM (2011) \\
\hline 4 & Berkeley_2 & 1825.98 & 8.6 & 0.01 & This study: WL (2011) \\
\hline 5 & Berkeley_2a & 1825.98 & 8.9 & 0.01 & This study: CSM (2011) \\
\hline 6 & Durbarton & 2694.0 & 6.3 & 0.016 & Marine and Siple (1974) \\
\hline 7 & CC-3* & 3435.04 & 2.6 & 0.001 & This study: WL (2012) \\
\hline 8 & CC-3* & 3759.84 & 2.1 & 0.0023 & This study: WL (2012) \\
\hline 9 & Norris Lightsey_1 & 3241.01 & 22.6 & 1.5 & CL (1984) \\
\hline 10 & Norris Lightsey_2 & 3243.01 & 23.8 & 2.2 & CL (1984) \\
\hline 11 & Norris Lightsey_3 & 3412.07 & 24.2 & 6.7 & CL (1984) \\
\hline 12 & Norris Lightsey_4 & 3475.07 & 27.7 & 3.7 & CL (1984) \\
\hline 13 & Norris Lightsey_5 & 4937.66 & 28.1 & 8.9 & CL (1984) \\
\hline 14 & Norris Lightsey_6 & 4993.44 & 32.5 & 6.9 & CL (1984) \\
\hline
\end{tabular}

*CC-3: Clubhouse Crossroad-3. ${ }^{\text {a }}$ Measurements of the Berkeley samples were repeated at the Weatherford and Colorado School of Mines (CSM) laboratories. Data sources: WL, Weatherford Laboratories, Golden, Colorado, USA; CSM, Rock Abuse Laboratory, Colorado School of Mines; CL, Core Laboratory Petroleum Engineering, Dallas, Texas. 